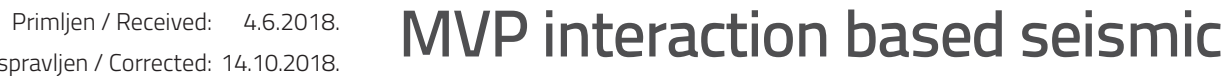 vulnerability assessment of RC buildings
}

Authors:

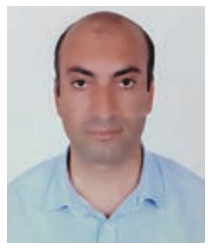

Assist.Prof. Barıș Erdil, PhD. CE

Van Yuzuncu Yil University, Turkey

Civil Engineering Department

bariserdil@yyu.edu.tr

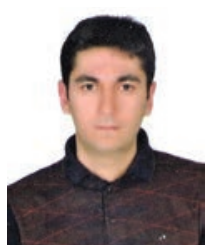

Harun Ceylan, MSc. CE

National Education Directorate, Turkey

Department of Construction and Real Estate

h.ceylan56@hotmail.com
Research paper

\author{
Barıs Erdil, Harun Ceylan
}

\section{MVP interaction based seismic vulnerability assessment of RC buildings}

Consuming less time as compared to detailed evaluation techniques, preliminary seismic vulnerability assessments are widely utilized worldwide. In this paper, a new procedure called MVP Method (moment (M), shear (V) and axial (P)), is proposed to evaluate seismic performance of RC buildings. The procedure needs structural and architectural parameters and considers the interaction of moment, shear, and axial load capacities and demands. Simple equations are proposed for each capacity and demand so as to calculate the building performance score. The proposed procedure was verified on 192 buildings, and the success rate ranged from 86.5 to $89.1 \%$.

Key words:

RC buildings, seismic vulnerability, vulnerability assessment, MVP method, bearing capacity

Prethodno priopćenje

\section{Barıș Erdil, Harun Ceylan}

\section{Primjena interakcijske metode MVP u ocjeni seizmičke oštetljivosti AB zgrada}

U svijetu se za ocjenjivanje seizmičke oštetljivosti često koriste preliminarne metode jer njihova provedba oduzima znatno manje vremena od detaljnih postupaka. U ovom se radu za ocjenjivanje seizmičkog ponašanja AB građevina predlaže novi postupak nazvan metoda MVP (moment (M), poprečno (V) i uzdužno opterećenje (P)). Za provedbu postupka potrebni su konstrukcijski i arhitektonski parametri, a analizira se interakcija kapaciteta nosivosti za moment, poprečno i uzdužno opterećenje te zahtjeve. Za svaki su kapacitet nosivosti i zahtjev predložene jednostavne jednadžbe za izračunavanje vrijednosti ponašanja građevine. Predloženi je postupak provjeren na 192 zgrade, a razina točnosti kreće se od 86,5 do 89,1\%.

\section{Ključne riječi:}

AB zgrade, seizmička oštetljivost, ocjena oštetljivosti, MVP metoda, kapacitet nosivosti

Vorherige Mitteilung

Barıș Erdil, Harun Ceylan

\section{Anwendung der MVP-Interaktionsmethode bei der Beurteilung der Erdbebenschäden von Stahlbetongebäuden}

In der Welt werden häufig vorläufige Methoden verwendet, um seismische Schäden zu bewerten, da deren Implementierung viel weniger Zeit in Anspruch nimmt als detaillierte Verfahren. In dieser Arbeit wird zur Beurteilung des seismischen Verhaltens der Stahlbetonkonstruktion ein neues Verfahren vorgeschlagen, das MVP-Verfahren (Moment (M), Quer- (V) und Längslast (P)). Zur Durchführung des Prozesses werden strukturelle und architektonische Parameter benötigt und das Zusammenspiel der Tragfähigkeit für Moment-, Quer- und Längslasten der Anforderungen analysiert. Für jede Tragfähigkeit und Anforderung werden einfache Gleichungen zur Berechnung des Wertes des Verhaltens eines Gebäudes vorgeschlagen. Das vorgeschlagene Verfahren wird an 192 Gebäuden überprüft, und die Genauigkeit liegt zwischen 86,5 und 89,1\%. 


\section{Introduction}

An earthquake with $M_{w}=7.4$ occurred on August 17, 1999 in Kocaeli, a province in northwestern Turkey, due to rupture of the North Anatolian fault. After three months, another earthquake with $M_{w}=7.2$ struck Duzce province on November 12, 1999 and affected the same region. Sultandağı, a town close to Afyon City, located in western Turkey, was hit by an earthquake of magnitude $M_{w}=6.2$ on February 3, 2002. A year after that, Bingöl City in eastern Turkey was struck by $M_{w}=6.4$ earthquake on May 1, 2003. On October 23, 2011 Van City, also located in eastern Turkey, was affected by an earthquake of magnitude $M_{w}=7.0$ and, after 17 days, i.e. on November 9, 2011, another earthquake with a magnitude of $\mathrm{Mw}=5.6$ struck the same region. Several minor and moderate earthquakes were also registered in other regions of Turkey [1]. Thousands of buildings collapsed or were severely damaged in those earthquakes, killing thousands of people. Besides, the economic loss was estimated to be in the vicinity of US $\$ 16$ billion for the Kocaeli earthquake only [2]. These collapses and severely damaged buildings are generally attributed to the low concrete grade, insufficient reinforcement detailing, inadequate workmanship, irregularities, etc. [3-7]. Although some buildings suffered moderate and minor damage only, this does not indicate that they have adequate strength and are safe for future earthquakes. Being vulnerable in a possible seismic event, their seismic performance should be determined to guarantee life safety and prevent future losses.

Seismic performance of RC buildings depends on several parameters; number of storeys, weight of the building, occupancy, concrete strength, reinforcement grade, detailing, soil conditions, architectural considerations, etc. Each parameter may have a strong influence in some cases. However, they generally interact with each other via a weighting factor. The weighting factor defines the level of seismic performance of buildings.

Three different approaches are available for determining seismic performance of RC buildings. The first approach is called the street survey (or walk-down procedure). It requires some basic visual properties of the building as well as predetermined scores that are assigned to each structural parameter [8-11]. By combining the scores, the final seismic performance score is calculated. This score is then compared to a cut-off value to determine the most vulnerable buildings in a building stock. The second approach is called the preliminary seismic vulnerability assessment or Level 2 assessment. It requires some basic calculations considering the load carrying characteristics of the building, soil condition, concrete strength, visual quality, and irregularities [8, 12-18]. Moreover, although all procedures in this group can be used to evaluate vulnerable buildings in a building stock, it can also be utilized to evaluate seismic performance of a single building with simple equations. The time required to complete a procedure is considerable when compared to procedures used in the street survey approach. Although some procedures are based on the capacity and demand relations [12,13,16-18], some use structural parameters and assign predetermined scores $[8,14,15]$. Besides, the number of parameters used in the procedures changes considerably, i.e. from 4 parameters [12] to 25 parameters [15]. The last approach includes detailed procedures which mainly require individual evaluation of each structurally important load carrying member. In these procedures, a detailed structural analysis, either linear or nonlinear, is necessary and more parameters are used when compared to the second approach [19-21]. The quality of parameters is higher since the procedures are based on the load carrying capacities and displacement abilities of individual members. As the approach is time consuming, it is not practical when a greater number of buildings is to be evaluated in a limited time.

Preliminary seismic vulnerability assessments are widely utilized because they consume less time as compared to detailed evaluation techniques. As previously noted, several methods are currently available and each of them has some strong and weak points. For example, the method proposed by Tezcan et. al. [15] is strong in terms of the number of parameters; however, it is weak in predetermined scores when a single value becomes dominant. In the same manner, the Hassan and Sozen [12] method is strong and practical when considering the ratio of the column and wall areas; however, it is weak when the behaviour is greatly influenced by irregularities and concrete quality.

Considering those strong and weak points in the existing procedures, a new procedure called MVP Method (moment (M), shear (V) and axial (P)), is proposed in this paper to evaluate seismic vulnerability of RC buildings. The procedure needs structural and architectural parameters and considers the interaction of moment, shear and axial load capacities and demands based on the observations from past earthquakes. Simple equations are proposed for each capacity and demand, in order to simplify the problem.

\section{Properties of investigated buildings}

192 buildings in Turkey with varying structural properties, located in three different cities, were taken into account in this study. 114 of the buildings are located in Van and 32 of them in Erciș, a town of Van City (some of the buildings are taken from [22]). In addition, 28 buildings are located in Bingöl and 18 in Afyon [23]

Seismic performance of a reinforced concrete building is dependant on several structural and architectural parameters such as the number of storeys (or height of the building), concrete strength, floor area, quantity of vertical load carrying members, infill wall, soft/weak storey, torsion, heavy overhang, quantity of longitudinal and transverse reinforcement, etc. The effects of some of the parameters on the damage state of investigated buildings are discussed below.

The number of storeys (in other words the height of the building) is reported to affect seismic performance of buildings [8]. Figure 1 shows the relationship between the number of storeys and the state of damage of 192 buildings investigated in this study. 
As can be seen, the number of storeys varies from 2 to 8 and the majority of buildings have 3, 4, and 5 storeys. It can also be noticed that there is no apparent relationship between the number of storeys and the state of damage between the second and the fourth storey. However, the damage starts to increase when buildings have more than 4 storeys. This observation is consistent with the findings of Sucuoğlu and Yazgan [8] who, after having investigated 477 buildings damaged in the 1999 Düzce Earthquake in Turkey, stated that the level of damage increases with the number of storeys. This was attributed to an inadequate seismic capacity.

The relationship between concrete strength $\left(f_{c}\right)$ and damage state is shown in Figure 2. Several reports presented after

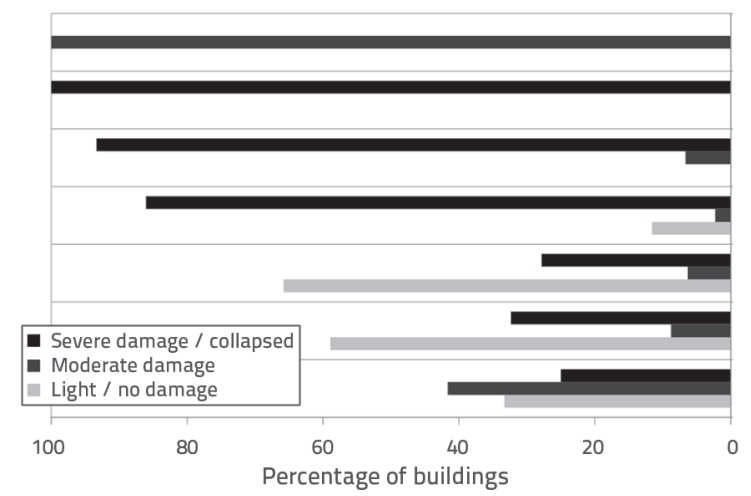

Figure 1. Relationship between number of storeys and state of damage

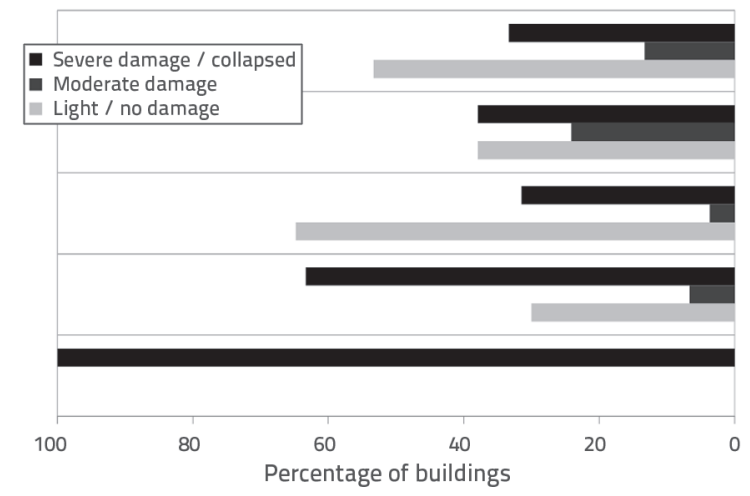

Figure 2. Relationship between concrete strength and damage state

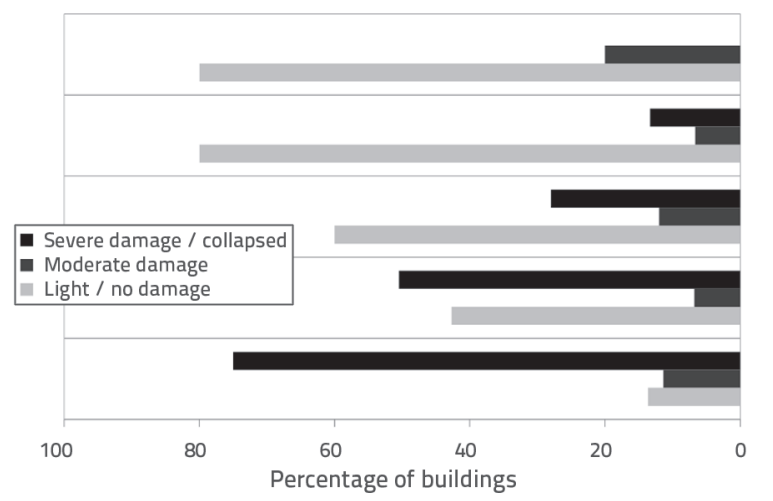

Figure 3. Relationship between ground floor area and damage state moderate to major earthquakes have revealed that concrete quality is not adequate in $\mathrm{RC}$ buildings $[5,7,22]$. This figure shows that only 15 buildings ( 7.8\%) exhibit the concrete strength greater than $20 \mathrm{MPa}$, which is the minimum limit specified in TEC2007 [21]. The concrete quality of the majority of buildings $(67 \%)$ is lower than $10 \mathrm{MPa}$, which means that these buildings exhibit the concrete strength that is lower than the minimum design strength calculated by dividing the characteristic strength by 1.5 , as specified in earthquake resistance codes. For example, according to TEC1997 [24] and TEC2007 [21] the minimum characteristic concrete strength is $20 \mathrm{MPa}$, and the design strength is $13.3 \mathrm{MPa}(20 / 1.5=13.3 \mathrm{MPa})$. It can be seen from the damage states that the percentage of severe damage/
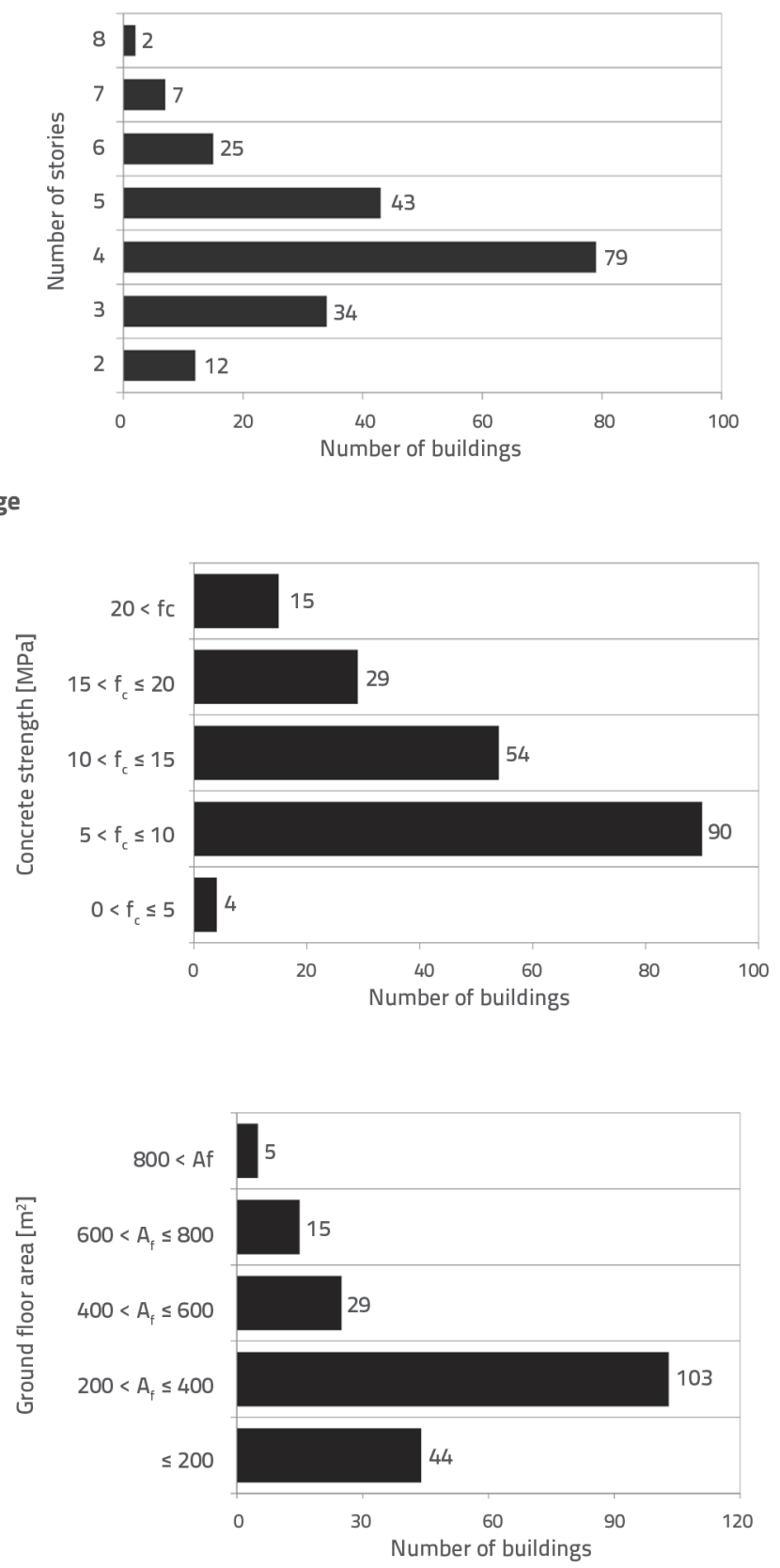

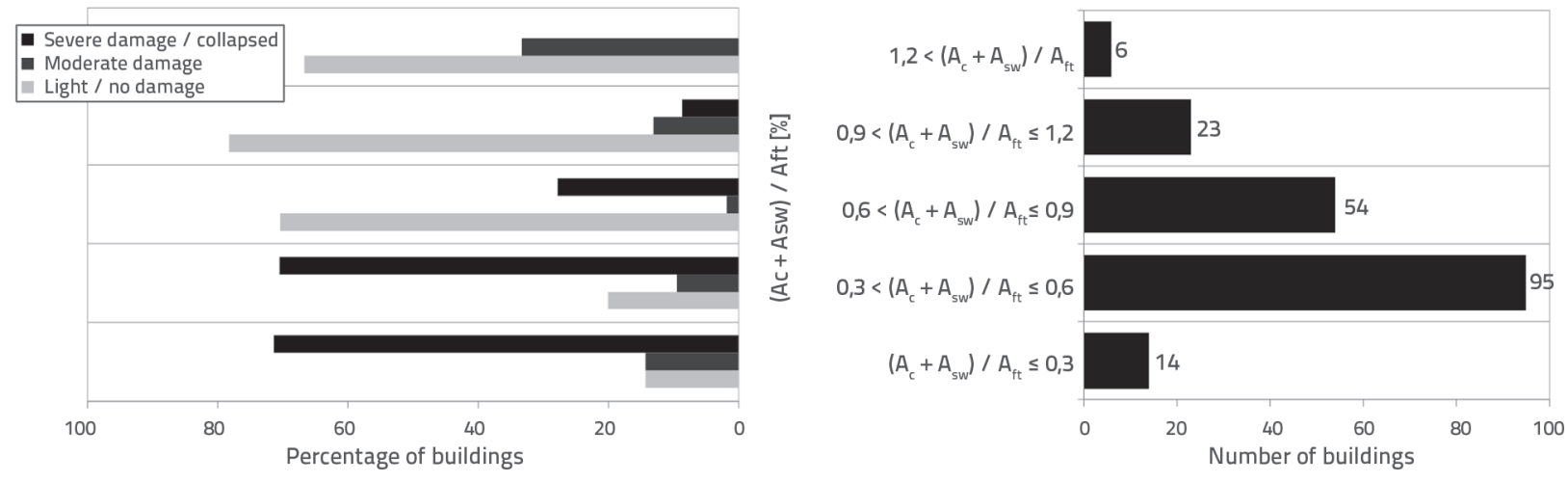

Figure 4. Relationship between the ratio of the total vertical load carrying members and damage state

collapsed buildings reduces as the concrete strength increases. Although the level of damage reduces with an increase in concrete strength, it was found that buildings with the concrete strength in excess of $20 \mathrm{MPa}$ still experienced severe damage/ collapse and moderate damage. It can therefore be inferred from the figure that concrete quality is not the only factor affecting the damage state of buildings.

The relationship between the damage state and the ground floor area is shown in Figure 3. It can be seen that most of the investigated buildings have the ground floor area of less than $400 \mathrm{~m}^{2}$. According to the damage state given on the left-hand side of the figure, the level of building damage reduces with an increase in the ground floor area. Although $75 \%$ of the buildings with the ground floor area of less than $200 \mathrm{~m}^{2}$ were severely damaged and collapsed, this percentage is only $13 \%$ for the buildings with the ground floor area between $600 \mathrm{~m}^{2}$ and $800 \mathrm{~m}^{2}$. Thus, it can be inferred from the figure that the ground floor area is an important parameter for the seismic resistance of buildings. However, being directly related to the area of the total load carrying members and the number of storeys, the ground floor area should not be regarded separately.

The relationship between the ratio of the total vertical load carrying members $\left(A_{c}+A_{s w}\right) / A_{f t}$ (where $A_{c}$ and $A_{s w}$ are the total column area and shear wall area on the ground floor, respectively, and $A_{f t}$ is the total floor area) to the state of damage is given in Figure 4 . The ratio $\left(A_{c}+A_{s w}\right) / A_{f t}$ of 14 buildings ( $7.3 \%$ of the buildings) is equal to or lower than $0.3 \%$, while it is equal to or lower than $0.6 \%$ for 109 buildings $(56.8$ $\%$ of the buildings). The ratio of total vertical load carrying members plays an important role in reducing building damage. In other words, the damage to the building decreases as the ratio of the total vertical load carrying members increases. It is obvious that $70.6 \%$ of the buildings with $\left(A_{c}+A_{s w}\right) / A_{f t}$ lower than $0.6 \%$ either experienced severe damage or collapsed. On the other hand, this ratio reduces to $6.9 \%$ for the buildings having $\left(A_{c}+A_{s w}\right) / A_{f t}$ greater than $0.9 \%$. However, since the buildings with high $\left(A_{c}+A_{s w}\right) / A_{f t}$ still fail during the earthquake, it can be concluded that $\left(A_{c}+A_{s w}\right) / A_{f t}$ cannot be used as the sole indicator of the state of damage.
In addition to the above parameters, the way in which damage state is influenced by some architectural parameters, such as soft/weak storey, short column, and heavy overhang, is given in Table 1. Among 86 buildings affected by soft/weak storeys, 57 $\%$ experienced either severe damage or collapsed. However, this does not mean that buildings affected by soft/weak storeys are highly vulnerable, because $43 \%$ of them exhibited moderate or light damage. The influence of heavy overhang is similar to that of the soft/weak storey, since $62 \%$ of the buildings either collapsed or were severely damaged. However, as for short column, it can be observed that this feature is not directly related to damage as $55 \%$ exhibited either light damage or no damage at all.

Table 1. Relationship between architectural parameters and damage state

\begin{tabular}{|c|c|c|c|}
\hline Damage state & $\begin{array}{c}\text { Soft/weak } \\
\text { storey }\end{array}$ & $\begin{array}{c}\text { Short } \\
\text { column }\end{array}$ & $\begin{array}{c}\text { Heavy } \\
\text { overhang }\end{array}$ \\
\hline Light/No damage & $26(30.2 \%)$ & $26(55.3 \%)$ & $17(25.0 \%)$ \\
\hline Moderate damage & $11(12.8 \%)$ & $10(21.3 \%)$ & $9(13.2 \%)$ \\
\hline Severe damage & $25(29.1 \%)$ & $7(14.9 \%)$ & $19(28.0 \%)$ \\
\hline Collapsed & $24(27.9 \%)$ & $4(8.5 \%)$ & $23(33.8 \%)$ \\
\hline Total & 86 & 47 & 68 \\
\hline
\end{tabular}

Some buildings also exhibited deficiencies with regard to longitudinal reinforcement. According to available data, $32 \%$ of severely damaged and collapsed buildings exhibit the longitudinal reinforcement ratio of less than $1 \%$ (minimum ratio for columns specified in codes). It was also observed that the transverse reinforcement of $71.4 \%$ of the buildings is spaced at the intervals of more than $100 \mathrm{~mm}$ (maximum spacing specified in codes). In the light of the above observations and discussions, it can be concluded that, although concrete quality, number of storeys, ground floor area, ratio of the vertical load carrying members and other structural and architectural parameters do affect the seismic performance of the buildings, their individual effects may not be indicative since the performance and damage is related to the combination of all effects. Therefore, instead of using a single parameter to comment on the seismic 
vulnerability of buildings, several appropriately proportioned influential parameters should be applied for that purpose.

As for the global aspect, 81 out of the total of 192 buildings experienced light damage or no damage. 17 buildings were moderately damaged, 58 buildings were severely damaged, and 36 buildings collapsed. Out of all the buildings, 98 buildings (with no damage, light damage and moderate damage, i.e. 51 $\%$ of the buildings) can be used after repair or strengthening, whereas 94 buildings (with severe damage and total collapse, i.e. 49 \% of the buildings) cannot be used for any purpose (Figure 5). Since properties of the buildings do not greatly differ from city to city, it is believed that these 192 buildings may represent the actual quality of buildings in Turkey.

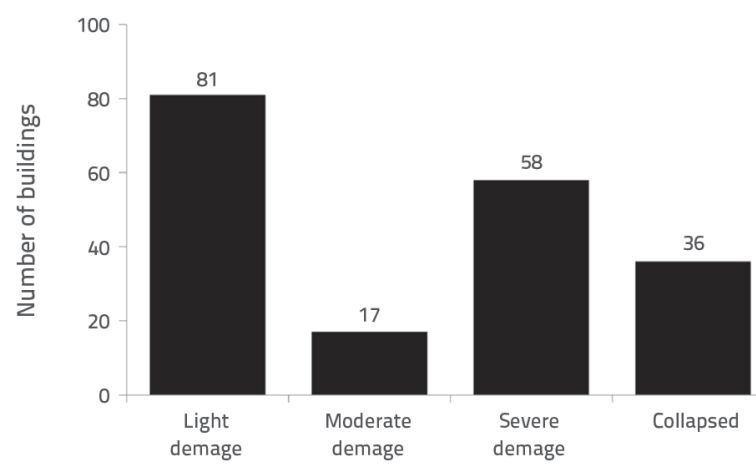

Figure 5. Damage to buildings

\section{MVP method}

Preliminary seismic vulnerability assessments should be reliable and yet simple to use since they require less time when compared to detailed procedures. The MVP method, presented in this text, aims to assess seismic vulnerability of buildings by utilizing their moment $(\mathrm{M})$, shear (V) and axial load (P) capacities, and then by comparing them with the demands calculated from simple equations. The moment-shear-axial load interaction is considered in the equation. Calculated MVP (where irepresents the earthquake direction - $x$ or $y$ direction - to be considered) is compared to the predetermined cut-off value to comment on the seismic vulnerability of buildings. If the score is greater than the cut-off value, then the building is thought to experience light/no damage, or moderate damage in a worst-case scenario. In this case, the building is regarded to be in the low vulnerability region. If the calculated score is lower than the cut-off value, the building is assumed to be in a highly vulnerable region and will probably experience severe damage or total collapse. The general form of the equation is given in Eq. 1.

$M V P_{i}=\frac{A}{\alpha \beta} \frac{M_{r i}}{M_{d i}}+\frac{B}{\gamma \varphi} \frac{V_{r i}}{V_{d i}}+C \frac{P_{r}}{P_{d}} \geq B P(1)$
In Eq. 1, $A, B$ and $C$ stand for the weighting factors to be determined in the following parts of the paper. $\alpha$ is the heavy overhang index, $\beta$ is the soft storey index, $\gamma$ is the short column index, $\varphi$ is the torsion index, $M_{r i}$ is the moment capacity of the building, $M_{d i}$ is the overturning moment due to earthquake load, $V_{r i}$ is the shear force capacity of the building, $V_{d i}$ is the base shear due to earthquake load, $P_{r}$ is the axial load capacity of the building, and $P_{d}$ is the external axial load. Although the ground storey is assumed to be the critical storey in this paper, the equation can also be used for other storeys as well. Each part of the equation is presented and discussed separately to enable understanding of its contribution and the idea behind it.

\subsection{Moment capacity and demand}

Moment capacity of an RC building consistent with the earthquake direction can be calculated using Eq. 2.

$M_{r i}=f_{y} \frac{L_{i}}{5} \sum \rho\left(A_{c}+A_{s w}\right)[\mathrm{kNm}]$

In the equation, $\rho$ represents the average longitudinal reinforcement ratio of the columns. If there is no information about longitudinal reinforcement, it can be taken as 0.008 when the building was constructed before the modern code (TEC1997 in case of Turkey [24]) and 0.01 after the modern code. $f_{y}$ shows the yield strength of longitudinal reinforcement (in case of no data one can use $220 \mathrm{MPa}$ for the buildings constructed in Turkey before 1997, and $420 \mathrm{MPa}$ after 1997), $L_{i}$ is the plan dimension of the building consistent with earthquake direction, and $i$ is the earthquake direction (either $x$ or $y$ ).

To construct the Eq. 2, it was assumed that a building can be represented by a cantilever column on which a point load acts at 2/3th of its height (Figure 6). In the building, the columns and shear walls are regarded as longitudinal reinforcement, as in a simple cantilever column. From Figure 6 , total tensile force $T$ is equal to,

$T=T_{1}+T_{2}+T_{3}=\sum T_{i}=\sum A_{s i} f_{s i}$

Where $T_{i}=A_{s i} f_{s i}$ is the total tensile force (Figure 6), $z_{i}$ is the moment arm, $A_{s i}$ is the area of longitudinal reinforcement, and $f_{s i}$ is the stress in steel.

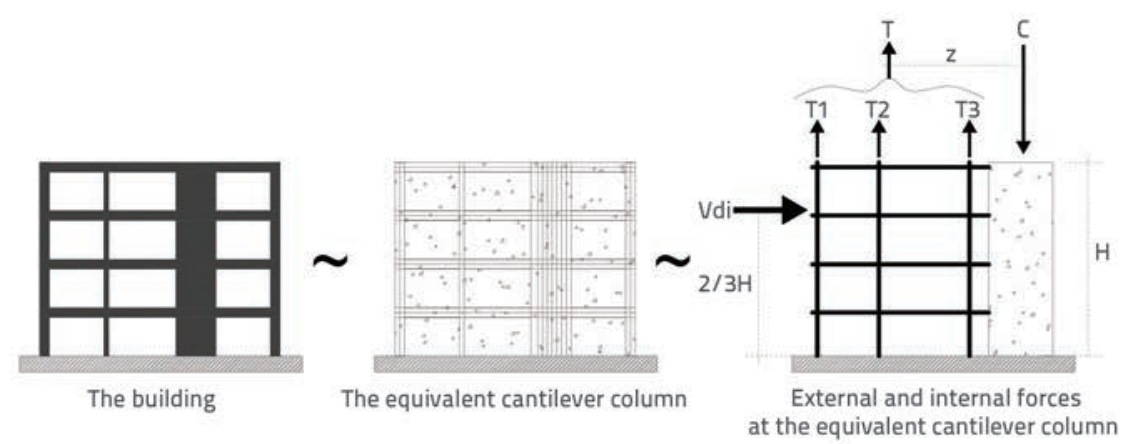

Figure 6. Equivalent cantilever column assumption for typical building 
In the cantilever building total tensile force, $T$, will be equal to,

$T=\frac{\rho\left(A_{c}+A_{s w}\right) f_{y}}{n_{1}}$

where $\rho\left(A_{c}+A_{s w}\right)$ stands for the total longitudinal reinforcement of the vertical load carrying members in a storey (similar to $A_{s i}$ in the cantilever column), and $n_{1}$ is the factor used to modify the equation so that only the reinforcements in the tension zone are considered. Here $A_{c}$ and $A_{s w}$ are the total area of the columns and shear walls in a storey, respectively.

Moment capacity of a cantilever building can be calculated quite simply, as shown in Eq. (5). The moment arm, $z$ is equal to $n_{2} L_{\text {, }}$ where $L_{i}$ is the plan dimension parallel to earthquake direction, $n_{2}$ is the modification factor to determine the moment arm for $T$.

$M=T Z$

Since the moment capacity will be misleading if the total reinforcement ratio is used, and the total plan dimension ( $L$ ) is considered in the moment arm, modification factors are used to end up with a reasonable moment capacity as given in Eq. (6).

$M=T z=\frac{\rho\left(A_{c}+A_{s w}\right) f_{y}}{n_{1}} n_{2} L_{i}=\rho\left(A_{c}+A_{s w}\right) f_{y} \frac{n_{2}}{n_{1}} L_{i}$

The moment arm of a bending member with several layers of longitudinal reinforcement is approximately equal to $0.8 \mathrm{~h}$ [27] and the effect of longitudinal reinforcement farther from the centroid is greater when compared to the one close to the centre. Considering this information, $n_{2}$ is assumed to be equal to 0.8. Moreover, the length of the building parallel to the earthquake direction is divided by 4 equal parts to create four sections on floor plan and, related to the above information, it is assumed that the longitudinal reinforcement further from the centroid is located at the far end of the tension side. With these assumptions, $n_{2} / n_{1}=0,8 / 4=1 / 5$ is obtained which modifies both the total reinforcement ratio and moment arm. Finally, the $M_{r i}$ is established as in Eq. (2) considering the strength and the ratio of the longitudinal reinforcement, area of the vertical load carrying members, and the plan dimension consistent with the earthquake direction. While constructing the $M_{r r^{\prime}}$ the effect of axial load is ignored since the axial load factor is considered separately in Eq. (1).

The value $M_{d i}$ i.e. the external moment due to the earthquake load consistent with earthquake direction, can be calculated from Eq. (7). In this equation, the base shear is assumed to act at $2 / 3 \mathrm{H}$ of the building, $\mathrm{H}$ being the total height of the building measured from the ground (basements are excluded). $V_{d i}$ is the base shear calculated for the direction that is being considered (the equation is given in the following sections).
$M_{d i}=\frac{2}{3} H V_{d i} \quad[\mathrm{kNm}]$

\subsection{Shear force capacity and demand}

The value $V_{r r^{\prime}}$ i.e. the shear force capacity of the building consistent with the earthquake direction, can be calculated as in Eq. (8).

$V_{r i}=1.4 f_{c t k}\left(\frac{100}{s}\right)^{0.7} \sum\left(A_{c i}+A_{s w i}\right) \quad[\mathrm{kN}]$

In the equation, i stands for the earthquake direction, $f_{c t k}$ is the tensile strength of concrete and can be calculated from $0.35 \sqrt{f_{c k}}$ where $f_{c k}$ is the characteristic compressive strength of the concrete (in $\mathrm{MPa}$ ), $s$ is the spacing (in $\mathrm{mm}$ ) of transverse reinforcement (shear reinforcement) in the confinement zone, $A_{c i}$ is the column area, and $A_{\text {swi }}$ is the shear wall area consistent with the direction considered. The equation considers vertical RC members, such as columns and shear walls, only. Moreover, it takes into account both concrete and reinforcement contribution with a single equation. Infill walls are not taken into account since their contribution to the load carrying capacity is low when compared to RC members. Although, $V_{r i}$ and $V_{r, \text { code }}$ both use concrete, transverse reinforcement, and area of the members as input data, the proposed equation simplifies the equation process by combining two separate equations for columns (Eq. 9) and shear walls (Eq. 10) available in TEC2007 [21] and TS500 [25].

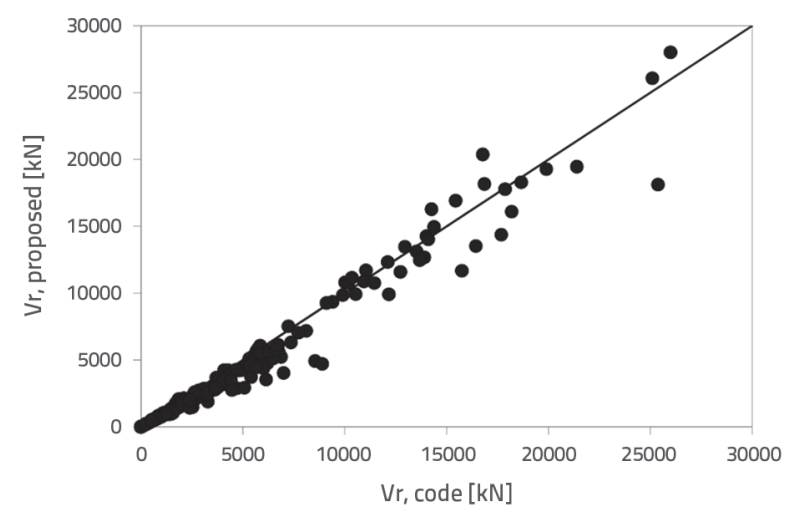

Figure 7. Comparison of the proposed shear capacity and the shear capacity calculated according to TEC2007

Figure 7 shows the comparison between the shear force capacity calculated from Eq. (8) and the one given in Eq. (9) and Eq. (10). It can be seen that the difference is not significant, indicating that results given in Eq. (8) are reasonable.

$V_{r, \text { code }(\text { column })}=0.65 f_{\text {ctk }} b_{w} d+\frac{A_{s t w}}{s} f_{y} d$

$V_{r, \text { code }(\text { shear wall })}=A_{s w}\left(0.65 f_{c t k}+\rho_{s w} f_{y}\right)$ 
In Eq. (9) and (10), $b_{w}$ is the short dimension of a column, $d$ is the effective depth of a section, $A_{s t w}$ is the area of transverse reinforcement of the column, and $\rho_{\sigma w}$ is the transverse reinforcement ratio in shear wall. Since columns and shear walls are strong when their long side is consistent with the earthquake direction, their capacity in perpendicular direction is ignored. In other words, while calculating the area of a rectangular column, one should first determine its long side, and then calculate the corresponding area. For example, assume that the long side of a column is in x-direction. If the long side of the column coincides with the earthquake in $x$-direction, then the area of the column $\left(A_{c x} A_{c y}=0\right)$ is calculated. Otherwise the contribution of that column is ignored and taken into account in the opposite direction $\left(A_{c x}=0, A_{c y}\right)$. If the column is square in cross-section, then the reader should consider the area of that column in both directions $\left(A_{c x}\right.$ and $\left.A_{c y}\right)$. This assumption should only be used to calculate $A_{c i}$. The same definition is also valid for shear walls. The base shear due to earthquake load consistent with earthquake direction $\left(V_{d}\right)$ can be defined using Eq. (11).

$V_{d}=\frac{S_{a} \sum W}{R}$

In the equation, it is assumed that each floor of the building weighs $12 \mathrm{kN} / \mathrm{m}^{2}$ (average value for the 40 buildings as indicated in Figure 8) and that $\Sigma W$ is equal to $\Sigma 12 A_{\text {floor }}$ where $A_{\text {floor }}$ is the plan area of the floor considered, $S_{a}$ is the spectral acceleration (assumed to be equal to 1 ), and $\mathrm{R}$ is the base shear reduction factor to be considered in shear design, which can be 2 according to the TEC2007 [21]. From these assumptions, the base shear equation can be simplified as in Eq. (12).

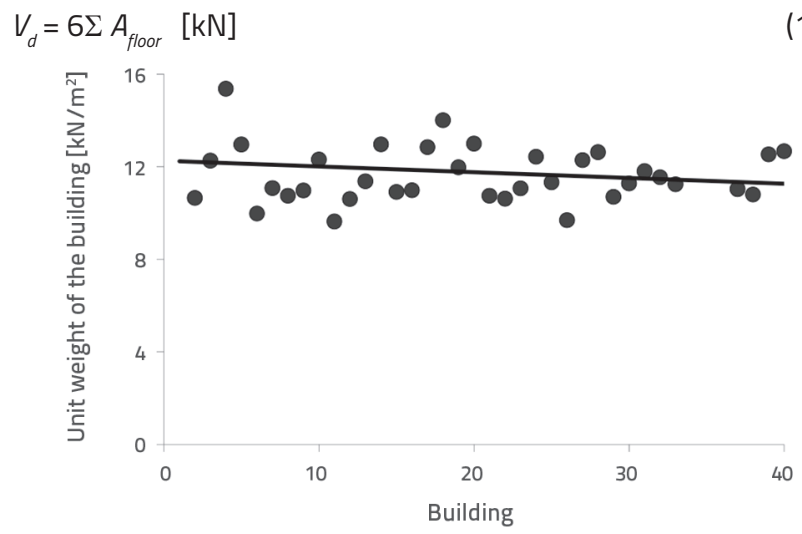

Figure 8. Unit weight of the building

\subsection{Axial force capacity and demand}

Axial force capacity of the vertical load carrying members can be calculated according to Eq. (13).

$P_{r}=f_{c k} \Sigma\left(A_{c}+A_{s w}\right) \quad[\mathrm{kN}]$
In the equation $A_{c}$ refers to the total column area and $A_{s w}$ is the total shear wall area for the storey under study. The concrete contribution is considered in the equation only to simplify the problem. Eq. (14) can be utilized to find the demand axial load.

$P_{d}=12 \Sigma A_{\text {floor }}[\mathrm{kN}]$

It is assumed in the equation that each floor of the building weighs $12 \mathrm{kN} / \mathrm{m}^{2}, \Sigma A_{\text {floor }}$ is the total floor area above the storey of concern.

\subsection{Heavy overhang Index " $\alpha$ "}

Since heavy overhang increases the moment in peripheral columns, its effect is taken into account in the global aspect. In order to understand the degree of increase in the moments, three buildings with similar properties were modelled (Figure 9). The first building (OHN) has no overhangs and is used as a reference model, the second one has $2 \mathrm{~m}$ overhangs supported by cantilever beams $(\mathrm{OH} 2 \mathrm{~B})$ and, finally, the last model has the same quantity of overhangs but the cantilever beams are absent $(\mathrm{OH} 2 \mathrm{~N})$. Overhangs were selected so that the maximum effect can be attained. After the linear static analysis, it was found that the average change in the moments of peripheral columns is 1.36 for $\mathrm{OH} 2 \mathrm{~B}$ and 1.33 for $\mathrm{OH} 2 \mathrm{~N}$. Therefore, it was decided to adopt $\alpha=1.4$ in the presence of an overhang and $\alpha=1.0$ when there is no overhang in the building.

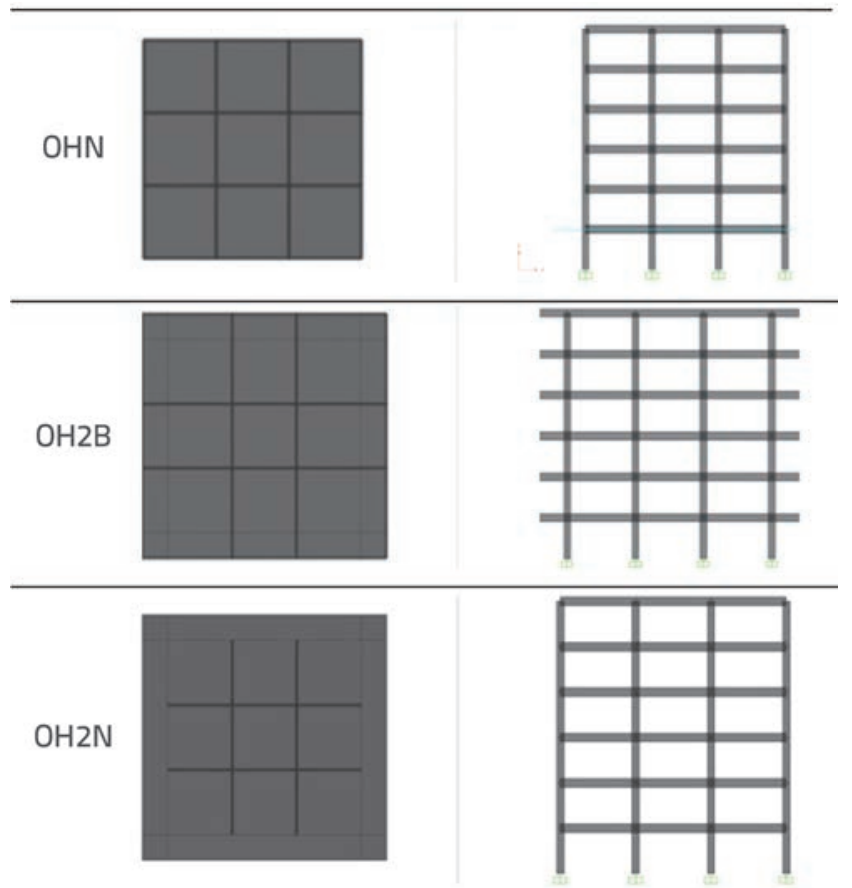

Figure 9. Models used to determine heavy overhang index

\subsection{Soft storey Index " $\beta$ "}

Similarly, three buildings were analysed to determine the change in moments due to formation of soft storeys. The first building has no 
soft storey (SSN), i.e. all storeys are $3 \mathrm{~m}$ in height. The second building has a soft storey and the ground floor is $4 \mathrm{~m}$ high (SS4) whereas the other ones are $3 \mathrm{~m}$ in height. In the last building, the ground floor is assumed to be $5 \mathrm{~m}$ high (SS5) and the remaining storeys are $3 \mathrm{~m}$ high (Figure 10). After the analysis of all buildings, it was established that the average increase in the moment is $20 \%$ for SS4 model and $40 \%$ for SS5, which confirms that the moments increase with an increase in the soft storey height. Therefore, considering average changes, it was decided to use $\beta=1.0$ when there is no soft storey in the building, and $\beta=1.4$ when soft storey exists.

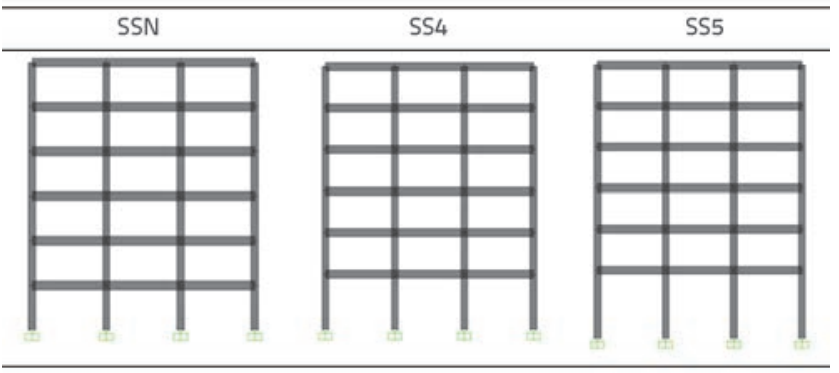

Figure 10. Models used to determine soft storey index

\subsection{Short column Index " $\gamma$ "}

Four simple frames were modelled in order to determine the effect of short column on shear force of a column, as shown in

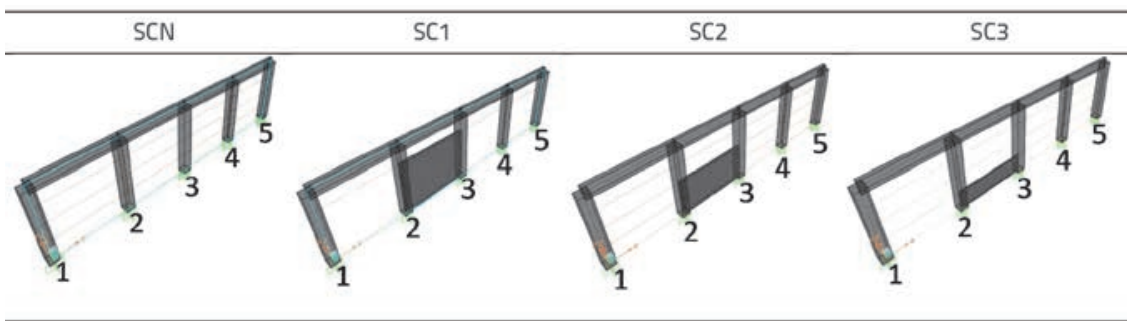

Figure 11. Models used to determine short column index

Table 2. Change in column shear forces due to short column formation

\begin{tabular}{|c|c|c|c|c|c|c|c|}
\hline \multirow{2}{*}{} & \multicolumn{4}{|c|}{ Column shear force [kN] } & \multicolumn{2}{c|}{ Change in column shear forces } \\
\cline { 2 - 8 } & SCN & SC1 & SC2 & SC3 & SC1/SCN & SC2/SCN & SC3/SCN \\
\hline Column 2 & 36.66 & 55.92 & 48.34 & 44.26 & 1.53 & 1.32 & 1.21 \\
\hline Column 3 & 33.93 & 48.49 & 44.71 & 41.31 & 1.43 & 1.32 & 1.22 \\
\hline \multicolumn{3}{|c|}{ Average change in column shear forces } & 1.48 & 1.32 & 1.21 \\
\hline
\end{tabular}
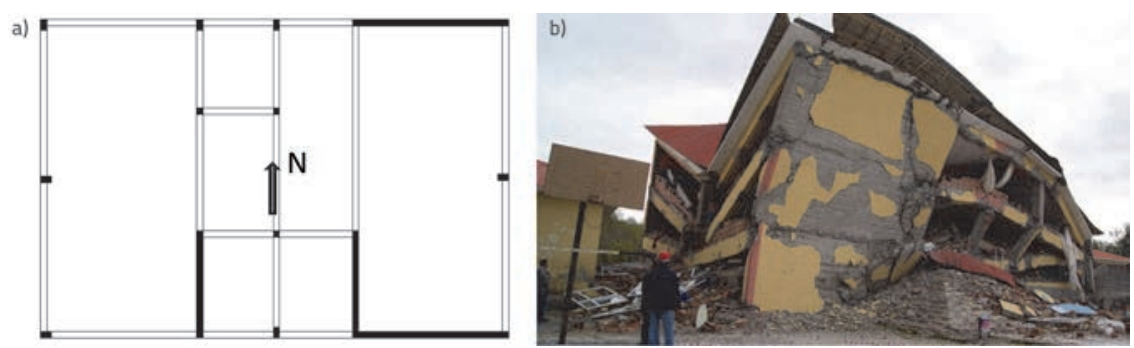

Figure 12. a) Structural plan of school in Gedikbulak village; b) collapsed school building
Figure 11. The SCN frame has no short column and is considered as the reference model. Short columns SC1, SC2 and SC3 measure $1 \mathrm{~m}, 2 \mathrm{~m}$, and $3 \mathrm{~m}$ in height, respectively. Neighbouring columns are $4 \mathrm{~m}$ in height. A constant lateral force was applied in the in-plane direction at the top left end, and each frame was analysed. Columns 2 and 3 are the ones affected by short column formation. As shown in Table 2, the maximum difference in column shear force reaches 1.53 , but the average column shear force is around 1.3. In order to increase the vulnerability score, the decision was made to use 1.4 in the presence of short column, and 1.0 when there is no short column formation.

\subsection{Torsion index " $\varphi$ "}

Torsion is one of the most unfavourable effects in structures, as it affects corner columns first and then spreads to peripheral columns. Column shear forces increase in case of torsional effects. If the corner and peripheral columns are not designed to resist the additional shear forces, then they are likely to suffer damage. A drastic example of this phenomenon was seen after the October 23, 2011 Van Earthquake. In a village called Gedikbulak, there was a three-storey school building whose plan is shown in Figure 12. The building had huge shear walls that were placed asymmetrically. The columns at the southwest and north-west corners were relatively small and were incapable of resisting additional shear forces. When subjected to lateral earthquake forces, the building collapsed because of torsional effects, as presented in Figure 12.b.

In the MVP method, torsion is assumed to increase the base shear. To understand the degree of torsion in the structure, three simple structures were created as indicated in Figure 13. In this figure, TN represents the symmetrical building with no torsional effect, T1 is the building exhibiting minor torsion since shear walls are placed close to the centre. The T2 building exhibits major torsion because shear walls are present at the corners. The linear elastic analysis was performed for the three structures and the changes in shear forces were recorded for columns. The results are summarized in Table 3 . It can be seen that shear forces increase by 1.67 times in corner columns in case of minor torsion and 2 times in case of major torsion. If the base shear is of concern, the increase in base shear is 1.29 times for minor torsion and 1.77 times for major torsion. As for the change in shear force for all columns, similar results are obtained for base 


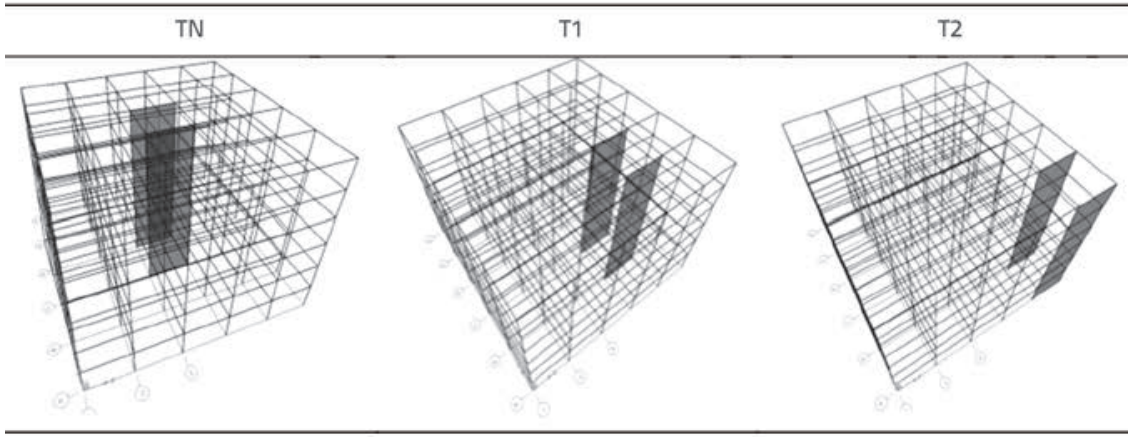

Figure 13. Models used to determine torsion indexes coefficient of 2 in shear design. Hence, no significant changes are mentioned in codes for moment capacities and applied moments, and the weighting factor $A$ is kept as 1. Accordingly, weighting factors of $A, B$ and $C$ amount to 1,2 and 0.2 , respectively. The final form of $M V P_{i}$ is given in Eq. (15).

$$
M V P_{i}=\frac{1}{\alpha \beta} \frac{M_{r i}}{M_{d i}}+\frac{2}{\gamma \varphi} \frac{V_{r i}}{V_{d i}}+0.2 \frac{P_{r}}{P_{d}}
$$

shear. Therefore, it can be concluded from results given in Table 3 that column shear forces increase by about 1.4 times for moderate torsion, while this increase is almost 1.9 times for the severe torsion. Accordingly, the torsion index is assumed to be 1.0 for no-torsion, 1.4 for moderate torsion, and 1.9 for severe torsion.

Table 3. Change in column shear forces due to torsion

\begin{tabular}{|c|c|c|}
\hline Shear forces & T1/TN & T2/TN \\
\hline Considering shear forces in corner columns only & 1.67 & 2.01 \\
\hline Considering total base shear & 1.29 & 1.77 \\
\hline Considering shear forces in all columns & 1.31 & 1.81 \\
\hline Average change in shear forces & 1.42 & 1.86 \\
\hline
\end{tabular}

\subsection{MVP Score}

After calculating the moment, shear and axial force ratio, the MVP score can be obtained using the interaction equation, Eq. (1). In this equation $A, B$ and $C$ are the weighting factors. Since shear and moments are governing forces in the design of reinforced concrete columns and shear walls, and those members are usually overdesigned in terms of axial load, the weighting factors for moment, shear and axial load should not be the same.

As the area of columns and shear forces is used to calculate the axial force capacity, the earthquake direction related to the strong or weak axis of those members is ignored and all columns are assumed to respond to all the axial forces. Therefore, a relatively low coefficient should be used in order to reduce the effect of axial capacity/load ratio. Choosing 0.5 for $C$ means that half of the columns are considered in either earthquake direction. To implement the overdesign factors (changing from 2 to 3 as in TEC2018 [26] but mostly 2.5), the decision was made to divide 0.5 by 2.5 to end up with 0.2 for $C$. As for the weighting factor $(B)$ of the shear capacity/force ratio, the same coefficient is used since the codes (TEC2007 and TEC2018) require an earthquake load reduction

\section{Assessment procedure and results}

Some points must be clarified when defining the MVP interaction equation. How to evaluate seismic vulnerability of a building using the MVP method? Can MVP score calculated in one-direction only (either $M V P_{x}$ or $M V P_{y}$ ) be used to evaluate seismic vulnerability of an RC building? If so, what is the cut-off value? If the combined MVP scores (MVPx + MVPy) is used, what will be the final evaluation?

In order to answer these questions, several analyses were performed, based on the data about 192 buildings, and the key parameters and evaluation results are discussed below. It should be kept in mind that this study categorizes the building vulnerability as "low vulnerability -LV" and "high vulnerability -HV". Undamaged, lightly damaged and moderately damaged buildings belong to LV category because these buildings can be used after a seismic event. Although moderately damaged buildings experience some structural damage, they need not be demolished because they can be used after proper strengthening. In other words, if it is possible to use a building either with or without strengthening after an earthquake, then that building is regarded as a LV building. Otherwise the building is considered to be HV building, and it is likely to experience severe damage or it may collapse. Although the figures given below indicate each damage level separately to see the difference between the buildings, in this text, the light damage, no damage, and moderate damage, will be regarded as LV, while severe damage and collapse will be considered as HV.

\subsection{MVP Method 1}

Considering the above discussion, MVP scores in each direction (Eq. 16 and Eq. 17) were calculated and the results were drawn as shown in Figure 14.

$$
\begin{aligned}
& M V P_{x}=\frac{1}{\alpha \beta} \frac{M_{r x}}{M_{d x}}+\frac{2}{\gamma \varphi} \frac{V_{r x}}{V_{d x}}+0.2 \frac{P_{r}}{P_{d}} \\
& M V P_{y}=\frac{1}{\alpha \beta} \frac{M_{r y}}{M_{d y}}+\frac{2}{\gamma \varphi} \frac{V_{r y}}{V_{d y}}+0.2 \frac{P_{r}}{P_{d}}
\end{aligned}
$$




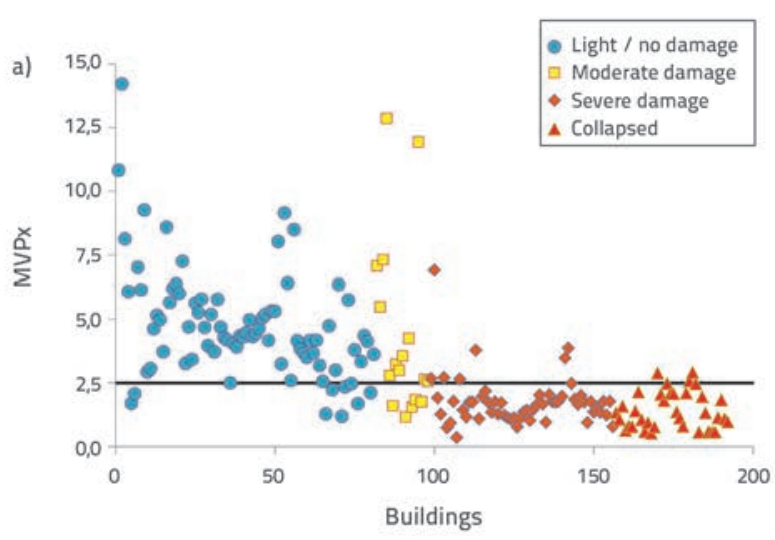

Figure 14. Results of: a) MVP ${ }_{x}$ b) MVP

In this figure, the hardest task involves setting a cut-off value to separate the LV buildings from HV buildings. It is obvious from MVP equations that the minimum score should be 3 for code conforming buildings, for which capacities are equal to the design forces and there are no irregularities in the building. This score somehow defines the life safety limit for ground motions having $10 \%$ probability of exceedance in 50 years. However, field observations revealed that some irregularities (not all irregularities at the same time) in the buildings were compensated by the load carrying members and life safety performance level was still applicable. Therefore, it was decided to lower the minimum score considering two irregularities at the same time which gave a score of 2.4. At first, this score is selected as a cut-off value and 192 buildings were evaluated accordingly. It was found that the number of the correctly estimated buildings was 166 (86.5\%) in $x$-direction and $163(84.9 \%)$ in $y$-direction. It is known that the rate of correct estimates is sensitive to the cut-off value. If a cut-off value was set to 2.6 , then the correct estimate rate decreased to $165(85.9 \%)$ in x-direction but increased to 166 $(86.5 \%)$ in y-direction. In order to simplify the problem and find an easy to remember value, a constant cut-off value of 2.5 was selected for both directions to evaluate seismic performance of buildings. Using this cut-off value, it was established that the seismic vulnerability level for 168 buildings $(87.5 \%$ ) was correctly estimated for $\mathrm{x}$-direction. As for $\mathrm{y}$-direction with the same cut-off value, the correct estimate was reduced to 165 buildings (85.9\%). This value may change with additional data. However, for the buildings considered in this paper, it was found that the seismic vulnerability level could be predicted correctly - based on this cut-off value - for a considerable number of buildings.

Separate evaluation for each earthquake direction may not be reasonable because buildings are usually designed in such a way that one direction is stronger than the other. In other words, if the evaluation is done considering the strong direction of the building only, then the building may be found in LV region, although it may be in HV region when the weak direction is of concern. Therefore, in order to find the reliable

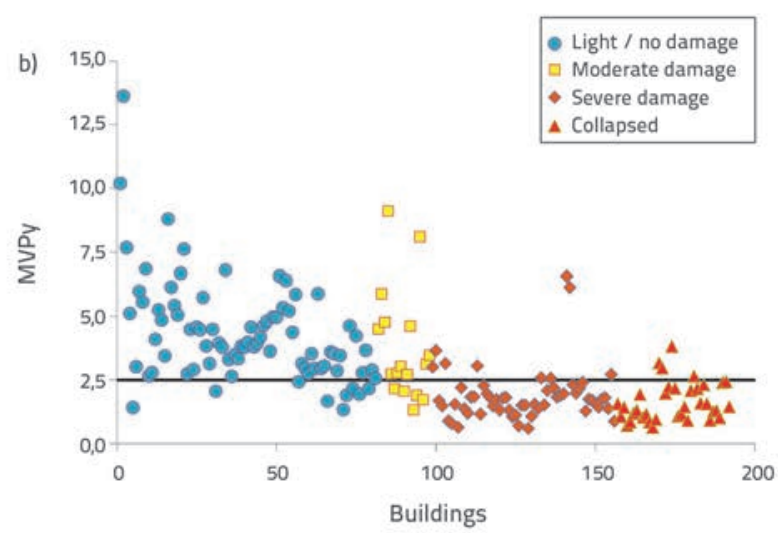

seismic performance of the building, it is recommended to use the interaction between the $M V P_{x}$ and $M V P_{y}$ given below. In this case assuming a cut-off value of 2.5 , one can use Table 4 to assign " 1 " if the $M V P_{i}$ score is less than 2.5. Otherwise, the score is equal to zero. For the final evaluation, if both $M V P_{x}$ and $M V P_{y}$ result in " $O$ " then the final score is " $O$ ". The final score is " 1 " in all other cases. Zero ("O") stands for LV and " 1 " represents HV. In Table 4, the values $S_{x}$ and $S_{y}$ stand for the score assigned in $\mathrm{x}$ - and $\mathrm{y}$-directions, respectively. FS denotes the final score that is found from the interaction between $S_{x}$ and $S_{y^{\prime}}$ Utilizing this procedure, it was established that the number of correct estimates is 166 buildings or $86.5 \%$ (Table 5). Though the number of the correctly estimated buildings is less than the one attained in evaluating buildings considering $x$-direction with a cut-off value of 2.5 , the combined procedure is recommended because it takes into account both directions at the same time.

Table 4. Evaluation from individual MVP's

\begin{tabular}{|c|c|c|c|c|}
\hline MVP $_{\mathbf{x}}$ & $\mathbf{S}_{\mathbf{x}}$ & MVP $_{\mathbf{y}}$ & $\mathbf{S}_{\mathbf{y}}$ & FS \\
\hline$\geq 2.5$ & 0 & $\geq 2.5$ & 0 & 0 \\
\hline$<2.5$ & 1 & $\geq 2.5$ & 0 & 1 \\
\hline$\geq 2.5$ & 0 & $<2.5$ & 1 & 1 \\
\hline$<2.5$ & 1 & $<2.5$ & 1 & 1 \\
\hline
\end{tabular}

Table 5. Correct estimate rates for the buildings considered in this paper

\begin{tabular}{|c|c|c|}
\hline Rate for MVP $_{\mathbf{x}}$ only & Rate for MVP $_{\mathbf{y}}$ only & Rate for table $\mathbf{4}$ \\
\hline $87.5 \%$ (168 buildings) & $85.9 \%$ (165 buildings) & $86.5 \%$ (166 buildings) \\
\hline
\end{tabular}

A building is usually designed in such a way that it has great strength and stiffness in one direction only. In other words, both directions do not have the same capacities because of the arrangement of load carrying members. As the capacity of a structure is not the same in opposite directions, their MVP score will be different since the method relies on capacities. Figure 15 shows this difference separately for LV and HV buildings. It 

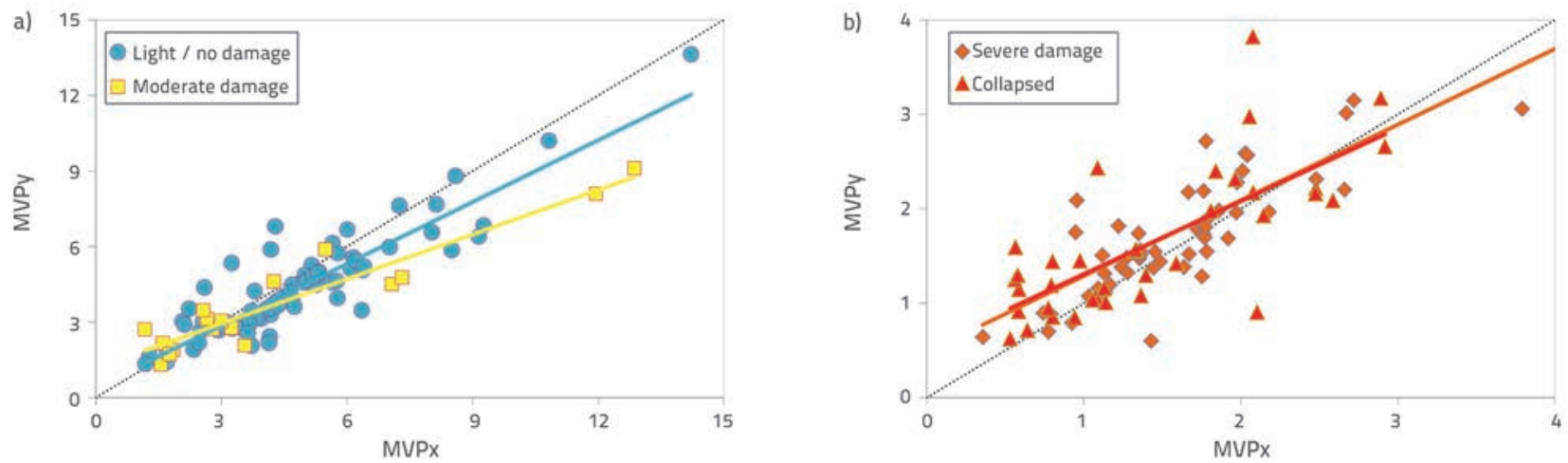

Figure 15. Comparison of MVP scores in opposite directions: a) Results for light damage, no damage, and moderate damage (LV); b) Results for severe damage and collapse (HV)

can be seen that MVP scores calculated in $\mathrm{x}$ direction - the long direction of the building - are generally higher than the ones for y direction. The difference is great in LV buildings. As for HV buildings, they seem to have higher capacities in short direction, but the difference is not so significant.

\subsection{MVP Method 2}

If one does not intend to use the above procedure, an alternative procedure is proposed as the MVP Method 2. In this method, MVP scores calculated for each direction are summed up as given in Eq. (18) and then the final MVP is found.

$M V P=M V P_{x}+M V P_{y}$

Since $M V P_{x}$ and $M V P_{y}$ are used to find MVP, the cut-off value was set to " 5 " meaning that if the MVP is greater than " 5 ", then the building is regarded to be in LV region, i.e., the building will either experience light/no damage or moderate damage. Otherwise, it has HV and severe damage may be expected. As stated in Figure 15, MVPs calculated for opposite directions may differ too much, i.e. one may be too low and the other may be too high, but their sum may be greater than 5. Since MVP Method 2 deals only with the sum, the final MVP score is important and, if it is greater than 5 , then the building is considered to be in $\mathrm{LV}$ region.

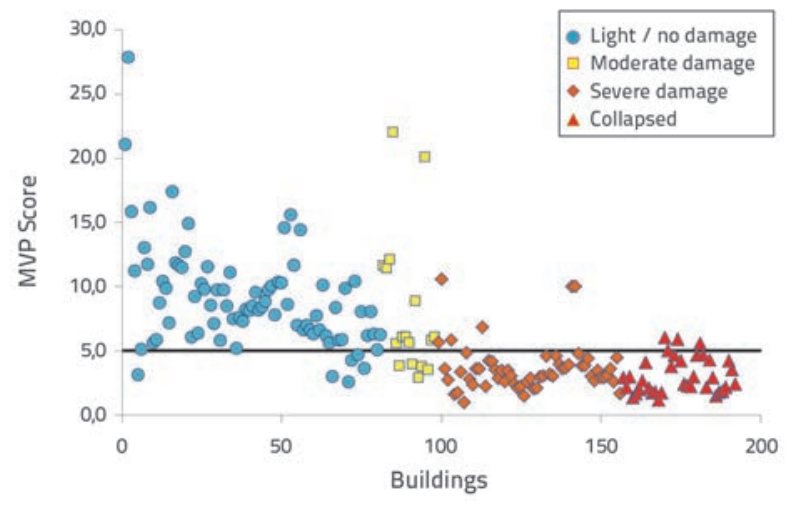

Figure 16. Results of MVP method
The results of all the buildings considered in this paper show that seismic vulnerability levels have been predicted successfully for most buildings (Figure 16). 84 buildings out of 94 severely damaged or collapsed buildings were evaluated as HV and the success rate was $89.4 \%$. In the same manner, 87 buildings out of 98 light/no or moderately damaged buildings were evaluated as LV, which corresponds to the success rate of $88.8 \%$. Overall the correct estimate was made for 171 buildings and the rate of accuracy was $89.1 \%$, which was higher compared to the MVP Method 1.

\section{Discussion}

Seismic performance of a reinforced concrete building may depend on several parameters such as the number of storeys, weight of the building, concrete strength, reinforcement grade, detailing, soil conditions, architectural considerations, etc. Each parameter may have strong influence in some cases but, generally, they interact with each other via a weighting factor. The weighting factors define seismic performance level of buildings.

There are several preliminary seismic assessment procedures for RC buildings such as Sucuoglu and Yazgan Level 2 [8], Hassan and Sozen method [12], Yakut's method [13], Özcebe et al method [14], Tezcan et al. method (also known as P25 method) [15], Otani's method [16] and Japanese standard for seismic evaluation of existing reinforced concrete buildings (JBDPA) [17]. These procedures are based on a total of 38 parameters as shown in Table 6. The numbers given in parenthesis show the number of usages of a particular parameter in different methods. For example, concrete strength is considered in 6 different methods. Column area and shear wall area are the only parameters that are used in all methods. They are followed by the weak storey and number of storeys, which are considered in all methods except for the Hassan and Sozen method [12]. Concrete strength and discontinuity (either slab or frame) appear in six different methods.

It can be seen in Table 6 that parameters differ according to the method used. For example, Hassan and Sozen [12] utilize only 4 
parameters, i.e. the total floor area, column area, shear wall area, and infill wall area. On the other hand, Tezcan et. al. [15] use as many as 25 parameters; earthquake zone, number of storeys, weight of the building, plan dimensions of the building, concrete strength, soil factor, foundation, stiffness factor, torsion, short column, weak storey, heavy overhang, discontinuity, pounding,

Table 6. Parameters considered in preliminary methods

\begin{tabular}{|c|c|c|c|c|c|c|c|c|}
\hline The Parameter & $\begin{array}{l}\text { Hassan \& } \\
\text { Sözen [12] }\end{array}$ & Otani [16] & JBDPA [17] & $\begin{array}{c}\text { Sucuoğlu } \\
\text { \& Yazgan } \\
\text { L2 [8] }\end{array}$ & $\begin{array}{c}\text { Özcebe et } \\
\text { al. [14] }\end{array}$ & Yakut [13] & $\begin{array}{c}\text { Tezcan et } \\
\text { al. [15] }\end{array}$ & $\begin{array}{l}\text { MVP } \\
\text { Method }\end{array}$ \\
\hline Basement (1) & & & $\sqrt{ }$ & & & & & \\
\hline Column area (8) & $\sqrt{ }$ & $\sqrt{ }$ & $\sqrt{ }$ & $\sqrt{ }$ & V & $\sqrt{ }$ & V & $\sqrt{ }$ \\
\hline Concrete strength (6) & & $\sqrt{ }$ & $\sqrt{ }$ & V & & $\sqrt{ }$ & V & $\sqrt{ }$ \\
\hline Cons. year (1) & & & $\sqrt{ }$ & & & & & \\
\hline Corrosion (1) & & & & & & & $\sqrt{ }$ & \\
\hline Discontinuity (6) & & V & $\sqrt{ }$ & $\sqrt{ }$ & $\sqrt{ }$ & $\sqrt{ }$ & $\sqrt{ }$ & \\
\hline Ductility (1) & & $\sqrt{ }$ & & & & & & \\
\hline Eq. zone (5) & & $\checkmark$ & V & $\sqrt{ }$ & & $\sqrt{ }$ & V & \\
\hline Foundation (1) & & & & & & & $\sqrt{ }$ & \\
\hline Grid Information (1) & & & & & $\sqrt{ }$ & & & \\
\hline Ground floor area (1) & & & & & $\sqrt{ }$ & & & \\
\hline Heavy overhang (5) & & & & $\sqrt{ }$ & $\sqrt{ }$ & $\sqrt{ }$ & $\sqrt{ }$ & $\sqrt{ }$ \\
\hline Height of the bldg. (2) & & & & & & & $\sqrt{ }$ & $\sqrt{ }$ \\
\hline Infill wall area (5) & & & & $\sqrt{ }$ & $\sqrt{ }$ & $\sqrt{ }$ & V & \\
\hline Load distribution effect (1) & & & & & & & V & \\
\hline Mezzanine storey (1) & & & & & & & $\sqrt{ }$ & \\
\hline Number of storeys (7) & & $\sqrt{ }$ & $\sqrt{ }$ & $\sqrt{ }$ & $\sqrt{ }$ & $\sqrt{ }$ & $\sqrt{ }$ & $\sqrt{ }$ \\
\hline Period of the bldg. (1) & & $\checkmark$ & & & & & & \\
\hline Plan dim.of bldg. (2) & & & & & & & $\sqrt{ }$ & $\sqrt{ }$ \\
\hline Pounding (2) & & & & $\sqrt{ }$ & & & $\sqrt{ }$ & \\
\hline Quality of the cons. (2) & & & V & & & $\sqrt{ }$ & & \\
\hline Reinf. ratio (1) & & & & & & & & $\sqrt{ }$ \\
\hline Reinf. strength (1) & & & & & & & & V \\
\hline Shear wall area (৪) & & $\sqrt{ }$ & $\sqrt{ }$ & $\sqrt{ }$ & $\sqrt{ }$ & $\sqrt{ }$ & $\sqrt{ }$ & V \\
\hline Short column (5) & & & V & $\sqrt{ }$ & & $\sqrt{ }$ & V & $\sqrt{ }$ \\
\hline Soil factor (3) & & $\sqrt{ }$ & $\sqrt{ }$ & & & & V & \\
\hline Stiffness factor (4) & & V & V & & V & & V & \\
\hline Storey height (2) & & & & & $\sqrt{ }$ & & V & \\
\hline Strong column criteria (1) & & & & & & & $\sqrt{ }$ & \\
\hline Time-dependent defr. (1) & & & V & & & & & \\
\hline Topography (2) & & & V & $\sqrt{ }$ & & & & \\
\hline Torsion (4) & & V & & & & $\sqrt{ }$ & V & V \\
\hline Total floor area (6) & & V & & V & V & V & & V \\
\hline Trans. reinf. spacing (2) & & & & & & & V & V \\
\hline Occupancy (2) & & & V & & & $\sqrt{ }$ & & \\
\hline Ground water table (1) & & & & & & & $\sqrt{ }$ & \\
\hline Weak storey (7) & & $\checkmark$ & V & $\sqrt{ }$ & V & $\sqrt{ }$ & V & V \\
\hline Weight of the bldg. (4) & & $\sqrt{ }$ & & & & $\sqrt{ }$ & V & $\sqrt{ }$ \\
\hline Number of parameters & 4 & 14 & 16 & 13 & 12 & 15 & 25 & 15 \\
\hline
\end{tabular}


topographical condition, storey height, column area, shear wall area, infill wall area, mezzanine floor, load distribution effect, corrosion, strong column criteria, height of the building, lateral tie spacing, and ground water table. The following methods are somewhere in between these extremes: Özcebe et. al. [14] use 12 parameters, Sucuoğlu and Yazgan [8] use 13 parameters, Otani [16] takes 14 parameters into account, Yakut [13] utilizes 14 parameters, and JBDPA [17] applies 16 parameters. In addition, 15 parameters are considered in the proposed MVP method.

192 buildings were assessed using the abovementioned methods and the ones proposed in this paper and the comparisons of the results are presented. Table 7 shows that the method proposed by Hassan and Sozen [12], which takes into account 4 parameters, is the most economical method in terms of time. However, number of parameters is not the only factor to be dealt with. The interaction between the parameters and location of the building plays an important role in defining seismic performance of buildings. Hassan and Sozen [12] developed a successful interaction between the four parameters and obtained the $67.2 \%$ success in predicting seismic performance of the buildings considered in this paper, as shown in Table 7. The correct estimate amounted to $80.6 \%$ in LV buildings whereas it was only $53.2 \%$ for HV buildings. The reason for the low percentage for HV buildings can be attributed to the absence of concrete quality in the method. Since most of the buildings considered in this paper have great amount of column and shear wall area, they ended up with higher performance scores and this led to wrong estimate.

Tezcan et. al. [15] use 25 parameters and, in addition, the method requires several steps to evaluate seismic performance of a building. After calculating the key factors and obtaining the final score for 192 buildings, it was established that the $75.5 \%$ success rate was achieved, as shown in Table 7. The method predicted correctly the $79.8 \%$ of HV buildings and $71.4 \%$ of LV buildings. However, the method does have a drawback, i.e. it requires some preassigned scores by the authors. Some preassigned scores that are close to or lower than the cut-off score may become dominant and lead to wrong estimation.
As for JBDPA [17], it was established that $100 \%$ of HV buildings are predicted correctly but the number of correct estimates was only $29.6 \%$ for LV buildings. Overall, the final correct estimate was $64.1 \%$. The high correct estimate for HV buildings is due to the cut-off score being high for the buildings considered in this paper. Since the method in JBDPA [17] was developed for the buildings in Japan, due to the differences in the construction and design technique, the cut-off score become high for the buildings in Turkey. Reducing the cut-off score to 0.6, it was realized that the correct estimate increased to $81 \%$.

Otani [16] uses a procedure similar to JBDPA with a reduced cutoff score, but the estimation accuracy is only $63 \%$. Yakut [13] considers the shear-based method, but the method is sensitive to the code base shear $\left(\mathrm{V}_{\text {code }}\right)$ that uses the earthquake load reduction factor. Utilizing a wrong reduction factor will result in a misleading seismic performance. The estimation accuracy of this method is 63.5\%. Sucuoğlu and Yazgan [8] Level 2 approach has only $52.1 \%$ correct prediction. Özcebe et. al. method [14] using similar properties as Sucuoğlu and Yazgan [8] Level 2 approach, is the least successful method. It was determined based on the Özcebe et. al. method [14] that the statistical tools need more studies to enable achievement of a higher success rate.

Contrary to the preliminary methods discussed above, the proposed MVP methods using the capacity vs. demand parameters seems to be the most successful (Table 7). The overall correct estimate in MVP Method 1 is $86.5 \%$, with $91.5 \%$ for HV buildings and $81.6 \%$ for LV buildings. Since this method requires separate evaluation of a building in each principal direction, the result differs from that obtained by the MVP Method 2 which considers the summation of MVP scores in principal directions. When summing up the MVP scores, the success rate increased to $89.1 \%$, i.e. seismic performance of 171 out of 192 buildings was predicted correctly. The correct estimate is found to be better compared to the available preliminary methods. The proposed MVP methods does not require any soil factor, and this may introduce some error, but the error rate seems to be low since seismic performance of a great number of buildings was evaluated correctly.

Table 7. Comparison of preliminary methods

\begin{tabular}{|l|c|c|c|c|}
\hline & Number of Parameters & $\begin{array}{c}\text { Overall correct estimate } \\
{[\%]}\end{array}$ & $\begin{array}{c}\text { Correct estimate } \\
\text { of HV buildings [\%] }\end{array}$ & $\begin{array}{c}\text { Correct estimate } \\
\text { of LV buildings [\%] }\end{array}$ \\
\hline Method MVP 2 & 15 & $\mathbf{8 9 . 1}$ & 89.4 & 88.8 \\
\hline Method MVP 1 & 15 & $\mathbf{8 6 . 5}$ & 91.5 & 81.6 \\
\hline Tezcan et al. (2011) & 25 & $\mathbf{7 5 . 5}$ & 79.8 & 71.4 \\
\hline Hassan \& Sozen (1997) & 4 & $\mathbf{6 7 . 2}$ & 53.2 & 80.6 \\
\hline JBDPA (2001) & 16 & $\mathbf{6 4 . 1}$ & 100.0 & 29.6 \\
\hline Yakut (2004) & 15 & $\mathbf{6 3 . 5}$ & 91.5 & 36.7 \\
\hline Otani (2000) & 14 & $\mathbf{6 3 . 0}$ & 97.9 & 29.6 \\
\hline Sucuoğlu \& Yazgan L2 (2003. & 13 & $\mathbf{5 2 . 1}$ & 21.3 & 81.6 \\
\hline Özcebe et al. (2003) & 12 & $\mathbf{4 1 . 7}$ & 9.6 & 72.4 \\
\hline
\end{tabular}


The ratio of correct estimates summarized in Table 7 is based on the vulnerability assumptions given in the preceding sections. Therefore, the rate of correct estimates may change when different classifications are used. As the proposed MVP methods have been developed using the data on 192 buildings with the properties given above, it may not be valid for all RC buildings. It is recommended to use this method for RC buildings with no more than 8 storeys.

\section{Conclusions}

MVP interaction based seismic vulnerability assessment of RC buildings is developed and tested by the data collected for192 buildings located in three different cities in Turkey. The buildings have a wide range of properties such as the number of storeys, concrete strength, floor area, area of the columns and shear walls, etc. The proposed MVP methods use moment, shear and axial load capacities as well as the demand moment, shear, and axial load. Some architectural and structural properties such as soft storey, heavy overhang, short column, and torsion, are also considered. While developing the MVP methods, it was assumed that all the buildings were in high seismicity region in order to simplify the problem. This assumption, together with the absence of soil condition, may be a deficiency of the MVP methods but, considering a high rate of prediction accuracy, this deficiency has quite a low impact on the results. However, the methods should be retested with a different database to verify this conclusion.

It is known that a complex equation with many parameters may lead to some mistakes in calculation. The mistake may be regarded as a blind mistake since the reader is not aware of that mistake and it is not intentional. Therefore, to minimize this blind mistake, simplified capacities and demands were developed in the proposed MVP methods. Definitions are not new for the reader but the organization and interaction may seem quite novel.

The MVP method can be utilized by means of two different approaches. In the first approach (called MVP Method 1) the reader can simply calculate seismic performance of a building considering each principal direction and then, comparing the MVP scores with a cut-off value of " 2.5 ", he/she assigns a score

\section{REFERENCES}

[1] KOERI: Boğaziçi University, Kandilli Observatory and Earthquake Research Institute, Regional Earthquake-Tsunami Monitoring Center, <http://www.koeri.boun.edu.tr/sismo/2/earthquakecatalog/> (Oct. 23, 2017).

[2] Erdik, M.: Report on 1999 Kocaeli and Duzce (Turkey) Earthquakes, Structural control for civil and infrastructure engineering, World Scientific, pp. 149-186, 2001, https://doi. org/10.1142/9789812811707_0018 (either 0 when the MVP score is greater than 2.5 or 1 when it is lower than 2.5). If any direction has a score of 1 , then the final score is " 1 " meaning that the building has HV in a seismic event. Otherwise, the building has a final score of " $O$ " and is regarded as LV. Using this approach, it was established that seismic performance of $86.5 \%$ of the buildings was predicted correctly. In the second approach (defined as MVP Method 2), the MVP scores calculated for each principal direction are summed up and the final MVP score is calculated. After that, the assessment of the seismic performance of the building is again evaluated by comparing the final MVP score with a cut-off value of " 5 ". This method provided a little increase in estimation accuracy. The number of correctly predicted buildings reached $171(89.1 \%)$.

As the preliminary methods available in literature were mainly developed from the database of a single country, they may not be so successful for another country. This is clearly seen for the methods proposed in $[16,17]$. Since a Japanese database was utilized in those methods, the cut-off value (the base score) was found to be great for Turkish database. With a reduced base score, it was realized that the methods can be used for the Turkish database as well. However, further study is needed to define a reasonable and representative cut-off value.

Other than the Japan-based methods, five different preliminary assessment methods developed from the Turkish database were utilized to compare the efficiency and success of the proposed MVP methods. It was realized that the success rate of MVP methods is greater compared to other methods. The close estimate rate is attained by Tezcan et. al. [15] with $75.5 \%$, although they used as many as 25 different parameters.

Each preliminary method has its own drawbacks and those drawbacks become important in different database. Considering this problem, three different databases were utilized while constructing the MVP methods in order to increase accuracy in predicting seismic performance of RC buildings. As a final conclusion, since the rate of correct estimate is high for the database used in this paper, the proposed MVP methods can be used to assess seismic vulnerability of a reinforced concrete building from simple calculations. It is recommended to use this method for RC buildings with maximum 8 storeys.
[3] Saatcioglu, M., Mitchell, D., Tinawi, R., Gardner, N.J., Gillies, A.G., Ghobarah, A., Anderson, D.L., Lau, D.: The August 17, 1999, Kocaeli (Turkey) earthquake damage to structures, Canadian Journal of Civil Engineering, 28 (2001) 4, pp. 715-737, https://doi. org/10.1139/cjce-28-4-715

[4] Sengel, H. S., Dogan, M.: Failure of buildings during Sultandagi Earthquake, Engineering Failure Analysis, 35 (2013), pp. 1-15, https://doi.org/10.1016/j.engfailanal.2012.09.011 
[5] Ozcebe, G., Ramirez, J., Wasti, S.T., Yakut, A.: 1 May 2003 Bingöl earthquake engineering report, TUBITAK, NSF. (http://www.seru. metu.edu.tr/archives.html), 2003.

[6] Akansel, V., Ameri, G., Askan, A., Caner, A., Erdil, B., Kale, Ö., Okuyucu, D.: The 23 October $2011 \mathrm{Mw}=7.0$ Van (Eastern Turkey) Earthquake: Interpretations of Recorded Strong Ground Motions and Post-Earthquake Conditions of Nearby Structures, Earthquake Spectra, 30 (2014) 2, pp. 657-682, https://doi. org/10.1193/012912EQS020M

[7] Bayraktar, A., Altunisik, A., Türker, T., Karadeniz, H., Erdogdu, S., Angin, Z., Özsahin, T.: Structural Performance Evaluation of 90 RC Buildings Collapsed during the 2011 Van, Turkey, Earthquakes, J. Perform. Constr. Facil., 2014, https://doi.org/10.1061/(ASCE) CF.1943-5509.0000524

[8] Sucuoglu, H., Yazgan, U.: Simple survey procedures for seismic risk assessment in urban building stocks,In: Wasti ST, Özcebe $\mathrm{G}$, editors. Seismic assessment and rehabilitation of existing buildings, earth and environmental sciences, London: Kluwer Academic Publishers, 29 (2003), pp. 97-118, https://doi. org/10.1007/978-94-010-0021-5_7

[9] Ministry of Environment and Urbanization (MEU): The Urban Renewal Law for Regions under Disaster Risk, Law No: 6306, Official Gazette, 28309, 52 (2012) (in Turkish)

[10] FEMA (Federal Emergency Management Agency): Rapid Visual Screening of Buildings for Potential Seismic Hazards - A Handbook, FEMA-154, Washington DC, 2002.

[11] Rainer, J.H., Allen, D.E., Jablonski, A.M.: Manual for Screening of Buildings for Seismic Investigation, National Research Council of Canada., 1993.

[12] Hassan, A, Sozen, M.A.F.: Seismic Vulnerability Assessment of Low-Rise Buildings in Regions with Infrequent Earthquakes, ACl Structural Journal, 94 (1997) 1, pp. 31-39, https://doi. org/10.14359/458

[13] Yakut, A.: Preliminary Seismic Performance Assessment Procedure for Existing RC Buildings, Engineering Structures, 26 (2004), pp. 1447-1461, https://doi.org/10.1016/j.engstruct.2004.05.011

[14] Özcebe, G., Yucemen, M.S., Aydogan, V., Yakut, A.: Preliminary Seismic Vulnerability Assessment of Existing Reinforced Concrete Buildings in Turkey - Part I: Statistical Model Based on Structural Characteristics, NATO Workshop, May, İzmir, Turkey, 2003, https:// doi.org/10.1007/978-94-010-0021-5_3
[15] Tezcan, S.S., Bal, I.E., Gulay, F.G.: P25 Scoring Method For The Collapse Vulnerability Assessment Of R/C Buildings, Journal of The Chinese Institute of Engineers, 34 (2011) 6, pp. 769-781, https://doi.org/10.1080/02533839.2011.591548

[16] Otani, S.: Seismic Vulnerability Assessment Methods For Buildings In Japan, Earthquake, Engineering and Engineering Seismology, 2 (2000) 2, pp. 47-56

[17] The Japan Building Disaster Prevention Association: Standard for Seismic Evaluation of Existing Reinforced Concrete Buildings, JBDPA, 2001.

[18] ASCE (American Society of Civil Engineers): Handbook for the Seismic Evaluation of Buildings-A Prestandard, Prepared for the Federal Emergency Management Agency, FEMA-310, Washington, D.C., 1998.

[19] ASCE (American Society of Civil Engineers): Prestandard and commentary for the seismic rehabilitation of buildings, FEMA356. Washington D.C., 2000.

[20] CEN. Eurocode 8 - Design of Structures for Earthquake Resistance, Part -1.: European Standard prEN 1998-1. Draft no. 4. Brussels: European Committee for Standardization; December 2001.

[21] TEC2007 (Turkish Earthquake Resistant Code): Specification for Buildings to be Built in Seismic Zones, Turkish Ministry of Public Works and Settlement, Ankara, Turkey, 2007.

[22] Erdil, B.: Why RC Buildings Failed in the 2011 Van, Turkey, Earthquakes: Construction versus Design Practices, Journal of Performance of Constructed Facilities, 31 (2016) 3, pp. 04016110, https://doi.org/10.1061/(ASCE)CF.1943-5509.0000980

[23] SERU (Structural Engineering Research Unit): Archival Material from Afyon and Bingöl Earthquake Database, Middle East Technical University, Ankara, Turkey. <http://www.seru.metu.edu. tr/archives.html> (August 23, 2017).

[24] TEC1997 (Turkish Earthquake Resistant Code): Specification for Structures to be Built in Disaster Areas, Turkish Ministry of Public Works and Settlement, Ankara, Turkey, 1997.

[25] Turkish Standards Institute: TS-500 Building Code Requirements for Reinforced Concrete. Ankara, Turkey, 2000 (in Turkish).

[26] TEC2018 (Turkish Earthquake Resistant Code): Deprem Etkisi Altında Binaların Tasarımı için Esaslar (Specifications for Buildings to be Designed under Seismic Effect), Turkish Ministry of Public Works and Settlement, Ankara, Turkey, 2018.

[27] Ersoy, U., Özcebe, G., Tankut, T.: Reinforced concrete, Middle East Technical University Press, Ankara, Turkey, 2010. 